\title{
TRENDS AND THE IMPLICATIONS OF CHANGE IN PUBLIC DEBT IN LATVIA
}

\author{
Aiga Apeinane ${ }^{1}$, Anda Zvaigzne ${ }^{2}$ \\ ${ }^{1}$ Faculty of Economics and Business Management, Rezekne Academy of Technologies, \\ Rezekne, Latvia, e-mail: aiga.apeinane@inbox.lv \\ 2 Dr.oec. associate professor, leading researcher, Rezekne Academy of Technologies, \\ Rezekne, Latvia, e-mail: Anda.Zvaigzne@rta.lv
}

Received: 22 July 2020 / Revised: 26 August 2020 / Accepted: 2 September 2020 /

Published: 30 November 2020

\begin{abstract}
An analysis of various research papers reveals that an increase in public debt has helped nations to restart economic growth; therefore, the research on public debt is still urgent and relevant.

The aim of the present research is to examine trends and the implications of change in the public debt of Latvia.

The research results revealed that over a ten-year period (2009-2018), the government budget of Latvia had a surplus only in one year (2016), which was due to the fact that the growth rate of budgetary revenues exceeded that of the national economy.

The research results also revealed that public debt explicitly had more negative than positive implications. The positive implications involve increases in income for the population (interest payments on debt securities) and revenue for the government budget (to cover expenditures). The negative implications of public debt for the national economy mostly involve a potential downgrade of the country's credit rating, which could lead to difficulties in raising funds during a crisis.

The research employed the following methods: monographic, induction and deduction, graphical, comparison, a sociological research method - expert surveying - and statistical analysis.
\end{abstract}

Keywords: economic growth, implications, national economy, public debt.

JEL code: $H 6, H 63, H 68$.

\section{Introduction}

A number of research studies indicate that public debt can both stimulate and hinder economic development (Ludvigson, 1996). An analysis of various research papers reveals that an increase in public debt has helped nations to restart economic growth; therefore, the research on public debt is still urgent and relevant.

In her monograph Government Debt: an Evaluation of Financial Security and Optimal Policy Selection, researcher N. Semjonova points out that public debt always plays a key role in any country's macroeconomic system. This could be explained by the fact that the creation, servicing and repayment of public debt make a large impact on the state of public finances, cash flow, the investment environment and the consumption pattern as well as the development of international relations (Semjonova, 2017). 
The aim of the research is to examine trends and the implications of change in the public debt of Latvia.

\section{Specific research tasks:}

1. To examine the theoretical aspects of the role of public debt in the national economy;

2. To examine trends in public debt and identify the implications of change therein.

Hypothesis: public debt causes both positive and negative implications for the national economy and economic growth.

The research employed the following methods: monographic, induction and deduction, graphical, comparison, a sociological research method expert surveying - and statistical analysis.

The research employed the specialist literature, relevant research papers and monographs, statistical data from the database of the Central Statistical Bureau of Latvia, the relevant national legal framework, as well as the data obtained from expert questionnaires and other publicly available information in the library and Internet resources.

\section{Literature review}

The government budget is a list of monetary revenues and expenditures, which is prepared for a certain period, usually one financial year (Šenfelde, 2014). In a situation where the government spends more than it can afford, public debt increases, which offsets the budget deficit. Conversely, according to researcher Levi M.D., if the government spends less than it can, there is a budget surplus that could be used to cover current debts (Levi, 2014). A government budget deficit leads to an increase in public debt, which is used to cover the government budget deficit with funds from short-term and longterm debt securities that are sold both domestically and abroad (Šenfelde, 2014).

In their research, G. Bua, J. Pradelli and A. Presbitero suggest four ways of covering the budget deficit, yet the ways are associated with the emergence of certain macroeconomic problems: 1. An issue of additional money can increase inflation; 2 . The use of foreign exchange reserves could lead to a currency crisis; 3. Borrowing from abroad can contribute to an external debt crisis; 4. Borrowing from domestic sources can boost interest rates and also lead to a debt crisis (Bua, et al., 2014).

In their research, H.S. Rosen and T. Gayer (Rosen, Gayer, 2014) conclude that the government could choose one of several options for covering its budget deficit, and the most common are an increase in public debt and changes in tax policy. From the perspective of efficiency, a question could be raised: what more contributes to the financial burden - public debt or taxes? 
The key to analysing this problem is an understanding that any increase in government spending has to be financed by higher taxes. The choice between public debt and taxation is only a matter of time - it is only a matter of choosing when higher taxes are applied. In case of tax revenue, one large payment is made when the expenditures are incurred. In case of borrowed funds, in contrast, a number of small payments are made to pay interest on the borrowed funds. In both cases, the present value of tax revenue must be the same (Rosen, Gayer, 2014). According to M. Šenfelde, public debt is basically an accrued budget deficit (Šenfelde, 2014).

Researchers J. Furman and L. Summers point out that a proper budgetary strategy should balance a number of competing considerations: it should move as much as possible towards economically viable policies, while remaining comprehensible and politically sustainable. From an economic perspective, an optimal policy could be a gradual reduction of expenditures or an increase in taxes to an extent that would prevent a continuous increase in public debt (Furman, Summers, 2019).

K. Vilerts explains that the amount of public debt in a country is affected by a number of factors, including the rate of economic growth, inflation, government bond yields and the government budget balance. However, the problem is that all the mentioned factors are interrelated, and that is why it is not possible to determine which of the factors affects a change in public debt (Vilerts, 2018). 0 . Tkačevs has concluded that public debt is particularly acute in the country following a financial crisis, as the government is forced to take measures to rescue the financial sector in a situation of declining gross domestic product (GDP) and tax revenues, or could use fiscal stimuli to revive the economy (Tkačevs, 2011).

The authors of the present research conclude that public debt, just like the debt of individuals or companies, arises in a situation of insufficient funds to implement a budgeted measure, i.e. a budget deficit arises. Consequently, the basic cause of public debt is government budget deficits, yet the size of it is determined by many other factors, e.g. inflation.

To be able to finance its expenditures, the government has two options higher taxes or public debt. Of course, higher taxes are a better solution fairer and more effective. The main problem with public debt, however, is that most often the debt has to be repaid, especially because it is in the interest of the lender (Piketī, 2015). Therefore, public debt is an alternative to raising tax rates or issuing additional money. In contrast to issuing additional money (creating higher purchasing power), an increase in public debt provides the exchange of purchasing power, i.e. the government borrows money from a lender (the lender lends its purchasing power) and pays interest on it. In contrast to the tax increase approach, an increase in public debt represents a deferral of payment of relevant expenditures (Fiscal 
Discipline Council, 2016). In some economies, mostly in industrialized ones, there is a fiscal rule that debt must be investment-oriented. This means that only this kind of debt is favourable (Galinski, 2015). Researchers A. Kamiguchi and T. Tamai point out that the golden rule of public finances allows for the possibility of borrowing to finance productive public investments that have the potential to pay off in a long term (Kamiguchi, Tamai, 2019).

The authors of the paper conclude that there are several ways of obtaining additional funds to cover the additional costs incurred: higher taxes, government debt and the issue of additional money. Each of the ways of obtaining funds has its advantages and disadvantages. Therefore, before making a decision, the national government has to take into account the possible implications of making a wrong choice.

Not only a large amount of financial resources but also tangible assets, i.e. buildings, equipment, gold and minerals are available to the government. However, public speeches focus mostly on public finances. Some economists, e.g. H. S. Rosen and T. Gayer, argue that disregarding the value of tangible assets gives an inaccurate picture of public finances (Rosen, Gayer, 2014). B. Dumitrescu points out that the degree of debt intolerance of a country depends on the past credit events, the rate of inflation in the country, the development stage of public institutions, the level of current public debt and the maturity structure thereof (Dumitrescu, 2014). According to G. Libermanis, public debt is divided into internal and external, and this division is determined by the source of the debt (Libermanis, 2001).

Internal debt basically means that the individuals of a country are in debt to each other. The experience of many countries shows that living with internal debt could be long and relatively peaceful (Šenfelde, 2014). Internal debt does not make any burden on future generations. The members of the next generation are, in simple words, in debt to each other. When the debt is repaid, the income is transferred from one population group (those who do not hold bonds) to another population group (bondholders). There are no negative conditions in such a situation because, at the level of consumption, everything occurs as it should (Rosen, Gayer, 2014). Internal debt is comprised of debt securities, savings bonds, interest-free bonds and loans from commercial banks.

Debt securities are securities certifying that the issuer has a liability to the holder of the security and that it has undertaken to make one or more payments to the holder of the security on a pre-agreed date. Debt securities are subject to an interest rate or a discount on the amount to be repaid on the redemption date of the security (Bank of Latvia, 2014). Savings bonds are a new kind of government securities that allow a wide range of people to use a safe alternative to investing and saving. In Latvia, the value of a savings 
bond is EUR 1; therefore, any resident of the country can afford to make investments in this kind of securities (Treasury, [s.a.]). Interest-free bonds are government securities that are intended for a special purpose, redeemed at their nominal value, not publicly available and not pledged as collateral as well as not disposed of. Such bonds (250 000 EUR in nominal value) are purchased by foreigners who wish to get a temporary residence permit for a period of up to five years (Treasury, 2017).

Accordingly, it could be concluded that internal debt basically represents fixed-interest rate and fixed-term securities issued by the government and voluntarily purchased by the residents of Latvia, as well as interest-free savings bonds voluntarily purchased by foreigners if they want to receive a residence permit in Latvia for a period of up to five years. In the case of such a source of funds to finance public debt, the amount of funds attracted cannot be influenced by the government.

External public debt consists of the amount of loans borrowed by residents from non-residents and repayable in a foreign currency or in goods or services. External public debt consists of long-term and short-term debt. Long-term debt consists of loans that have to be repaid over a period of more than one year, as well as loans that banks, individuals and businesses are granted without government guarantees. Short-term debt, in contrast, consists of public and private loans that have to be repaid in up to one year. Short-term debt also includes outstanding principal and interest payments on long-term borrowings (Birka, 2013). The securities representing external public debt are those purchased by foreigners.

With regard to external debt, it should be noted that it is mandatory to repay it, which is done by allocating a part of national income for this purpose. A failure to repay external debt, however, could also have serious political implications. For this reason, external debt is taken more seriously than internal debt (Šenfelde, 2014). In a situation where the government attracts foreign capital, liabilities to foreign countries increase. The ability to repay such a debt depends on the efficiency of use of national and foreign currency savings (Kasalis, Skribāne, 2007).

\section{Methodology}

The present research employed the monographic and descriptive methods, which helped to find a detailed idea of the problem researched from a theoretical perspective, based on an extensive review of the scientific literature.

The present research also employed induction and deduction, the graphical method, comparison, a sociological research method - expert surveying - and statistical analysis. 
An expert questionnaire was developed to identify the opinions of industry experts on issues pertaining to public debt. The expert questionnaire consisted of six questions - both open-ended and with options for giving a rating on a 5-point scale. The responses were received from five experts - employees of commercial banks (two experts) and academic personnel (two experts) and a public administration specialist with in-depth knowledge and experience in macroeconomics.

\section{Research results}

Cabinet Regulation No. 842 of 8 November 2005 "Regulations regarding the Classification of General Government Debt" of the Republic of Latvia states that general government debt is the gross debt (received and outstanding) of government structures, local government structures and social insurance structures at nominal value in the following categories of financial instruments: deposits, debt securities (excluding financial derivatives) and loans (Regulations..., 2005).

In the period 2009-2018, according to the data from the Central Statistical Bureau (CSB) database, (General government debt by sub-sector and quarter at end of period (mln euro), 2019) the general government debt of Latvia as a percentage of GDP was in the range of 36-43\%. In accordance with the Law on Fiscal Discipline of the Republic of Latvia passed on 31 January 2013, general government debt may not exceed $60 \%$ of GDP (Law on..., 2013). In the period 2009-2018, the highest ratio of general government debt to GDP was in 2011 (43.08\%). From 2009 to 2011, the general government debt-to-GDP ratio increased by 6.91 percentage points or $19.1 \%$. This could be explained by the fact that in the period 2008-2010, there was a global economic crisis that affected all countries. In this case, the general government debt increased because of government measures taken in response to the financial crisis and aimed at stabilizing the financial sector. After 2010, the government debt-to-GDP ratio continued to gradually decline, reaching $39.4 \%$ in 2013, while in 2014 it slightly increased to $40.87 \%$; in the following year (2015), the ratio sharply decreased to $36.66 \%$ (by 4.21 percentage points or $10.3 \%$ ). According to the CSB, the increase in general government consolidated debt was due to two issues of Eurobonds in 2014, which were implemented to refinance the current loans from the European Commission, which were received under the international bailout programme (The general government budget deficit in 2014 was $1.4 \%$ of GDP, 2015). The next increase in the general government debt-to-GDP ratio was reported in 2016, when it reached the level of $40.25 \%$. This could be explained by the fact that in 2016 funds were accumulated to repay outstanding debts. In 2016, the government of Latvia continued to repay the 
government debt borrowed from the World Bank in 2012 to deal with the consequences of the financial crisis. It is planned to completely pay back the loan in 2020, thereby repaying the loan gradually (Fridrihsone, 2017). Since 2016, the general government debt has continued to decline, reaching 36.36\% of GDP in 2018. In 2018, Latvia repaid Eurobonds issued in 2008 (in the amount of EUR 400 million) and redeemed domestic bonds (EUR 220.9 million); the funds were obtained by issuing Eurobonds in international financial markets in 2017 (LETA, 2019).

In their research Growth during Debt, US economics professors K. Rogofs and C. Reinhardt concluded that the critical level of public debt in developed countries, above which there is a threat to economic development, is $90 \%$ of GDP, whereas in developing countries this threshold is lower (Reinhart, Rogoff, 2010).

The public debt-to-GDP ratio increases mostly because of three factors:

1. The government implements a stimulating fiscal policy (spending exceeds tax revenues collected);

2. The borrowing rate is higher than the GDP growth rate;

3. A change in the government's financial investment policy or a change in the valuation of government debt (Tkačevs, 2011).

The authors of the paper conclude that the public debt-to-GDP ratio in Latvia in the period 2009-2018 did not exceed 43.8\%, which was the highest ratio reported in 2011; it was due to receiving a new loan to deal with the consequences of the financial crisis in the national economy. Undoubtedly, the changes in the public debt-to-GDP ratio over the period analysed were affected by the receipt of new loans or the repayment of previous loans.

The research results based on CSB data revealed that over a ten-year period (2009-2018), the government budget of Latvia had a surplus (in the amount of EUR 16.097 million) only in one year (2016), which was due to the fact that the growth rate of budgetary revenues exceeded that of the national economy. Overall, the situation is that in the event that a sufficient amount of revenue is received, the government does not need to borrow, which in turn reduces the budget deficit and does not require new borrowings. Accordingly, the key priority of the government is to contribute to increases in budget revenues without creating a too high tax burden for citizens as well as businesses.

Covering government expenditures by means of an increase in public debt might be more effective on the demand side of labour (no increase in the tax burden on labour), yet it is less effective concerning capital allocation decisions. A priori, it is not clear which is more effective (increase in debt or taxes) (Rosen, Gayer, 2014).

The authors of the paper believe that the Ministry of Finance of the Republic of Latvia should vary the methods of covering the government 
budget deficit and find a balance between an increase in public debt and changes in tax policies, thereby not reaching a public debt level that might cause financial difficulties not only for the government but also for the society as a whole.

Examining a breakdown of the general government debt of Latvia by subsector (Central Statistical Bureau database, 2019) allows us to conclude that overall, the amount of general government debt in the period 2014-2018 has been variable. In 2018 compared with 2014, the general government debt was EUR 3,259.465 million or 8.37\% higher. By far the highest proportion in total general government debt in the period 2014-2018 was represented by debt securities, most of which were long-term debt securities (74.81\% in 2018), followed by loans (23.14\% in 2018), while deposits had the lowest proportion $(2.05 \%$ in 2018).

N. Semjonova (Semjonova, 2017) points out that public debt is characterized not only by negative but also by positive features. The ability to use debt effectively is largely determined by the overall level of economic development, macroeconomic equilibrium, the government's economic priorities and the trust of individuals and legal entities in the government. Government borrowing plays an important role in ensuring economic development, which raises the objective of building an optimal system of public administration to a priority category. In this regard, the most important objective is to ensure a continuous governance process, and public debt policies must be able to respond quickly to changes in the economic situation in a short period. In order to achieve the objective, it is necessary to have a good knowledge of the structure of public debt when making any decision.

Within the present research, the authors assessed the impact of public debt on the national economy and summarized the positive and negative implications of an increase in public debt, see Table 1.

As shown in Table 1, public debt certainly has more negative than positive implications. The positive implications involve increases in income for the population (interest payments on debt securities) and revenue for the government budget (to cover expenditures). The negative implications of public debt are faced mostly by the population, both in a short and a long term. It should be emphasized that the repayment of public debt is financed from government budget revenues, which mostly consist of tax revenues paid by natural and legal persons. Accordingly, benefiting from the government support measures taken now means paying for them in the future. 
Table 1. Summary of the positive and negative implications of public debt (authors' compilation)

\begin{tabular}{|c|c|}
\hline Positive implications & Negative implications \\
\hline $\begin{array}{l}\text { 1. The amount of government } \\
\text { expenditures that are used to } \\
\text { perform functions important to the } \\
\text { society is increased; } \\
\text { 2. Individuals who purchase } \\
\text { government debt securities are } \\
\text { provided with income from future } \\
\text { capital gains. }\end{array}$ & $\begin{array}{l}\text { 1. The country's credit rating might be } \\
\text { downgraded; } \\
\text { 2. Loans become more expensive - loan interest } \\
\text { rates increase; } \\
\text { 3. The burden is placed on future generations; } \\
\text { 4. A part of national income is paid to creditors; } \\
\text { 5. The attractiveness of the country among } \\
\text { investors decreases; } \\
\text { 6. A number of fiscal measures could be taken to } \\
\text { repay public debt, which might reduce the } \\
\text { disposable income of the population and in turn } \\
\text { lower the living standard. }\end{array}$ \\
\hline
\end{tabular}

The authors of the paper found a moderately strong correlation between general government debt and general government expenditure (correlation coefficient 0.65 ); therefore, it could be argued that an increase in public debt increases government expenditures (initially government revenue), which are intended, for example, to cover the costs of social protection for the population. In this case, the positive implications of public debt for the national economy and the society as a whole could be stressed.

The authors of the paper conclude that many researchers emphasize the clear implications of public debt for the future growth of the national economy. However, it should be noted that an effect is made not only on the national economy as a whole but also on the living standard of the population of each country individually.

The expert survey conducted within the present research identified the experts' opinions on the positive and negative implications of public debt for economic growth.

The experts' ratings revealed that the most important positive or negative implications of public debt were an increase in the government budget (positive implications), which was rated at an average score of 4.2 points, as well as a potential downgrade of the country's credit rating (negative implications), which was rated at an average score of 4.2 points. The importance of an increase in government budget size could be explained by the fact that as the government budget size increases, the government's expenditures, which could be used to fund measures important to the society, increase as well. However, a potential downgrade of the country's credit rating is important because of its impact on the refinancing rate for current borrowings. An important fact was that the government of Latvia started implementing various fiscal measures with the aim of reducing the public debt; the implications were rated at an average score of 4 points. One 
of the experts interviewed believed that when rating the fiscal measures implemented, it was necessary to take into account when the fiscal measures were implemented. During a crisis, a government budget deficit and an increase in public debt is advisable, as the public expenditure multiplier affects GDP and aggregate demand increases, thereby helping the country to overcome the crisis. However, the situation where the public debt continues to grow even during an economic boom should be viewed negatively.

According to the experts, a decrease in the country's attractiveness to investors represented unimportant implications of public debt. One of the experts believed that the country's attractiveness to investors depended on a number of factors and was not affected by public debt. The experts were divided on the fiscal measures taken to reduce public debt.

Overall, it could be concluded that, according to the experts who rated the implications of public debt for economic growth, an opportunity to increase the government budget was considered positive and important, which allows implementing the measures being important for the society and requiring additional funding. The most important negative implications involved a potential downgrade of the country's credit rating, thereby reducing the possibility of obtaining a loan or attracting investors on favourable terms and conditions later.

\section{Conclusions}

1. Public debt plays a key role in the macroeconomic system of any country. It can both stimulate and hinder the development of the country's economy.

2. Public debt, just like the debt of individuals or companies, arises in a situation of insufficient funds to implement a budgeted measure, i.e. a budget deficit arises. Consequently, the basic cause of public debt is government budget deficits, yet the size of it is determined by many other factors, e.g. inflation.

3. Over a ten-year period (2009-2018), the government budget of Latvia had a surplus only in one year (2016), which was due to the fact that the growth rate of budgetary revenues exceeded that of the national economy.

4. The hypothesis proved to be true, as public debt causes both positive and negative implications for the national economy and economic growth. However, it should be noted that public debt explicitly has more negative than positive implications.

5. According to the experts who rated the implications of public debt for economic growth, an opportunity to increase the government budget was considered positive and important, which allows implementing the 
measures being important for the society and requiring additional funding.

6. The most important negative implications involved a potential downgrade of the country's credit rating, thereby reducing the possibility of obtaining a loan or attracting investors on favourable terms and conditions later.

7. The Ministry of Finance of the Republic of Latvia should vary the methods of covering the government budget deficit and find a balance between an increase in public debt and changes in tax policies, thereby not reaching a public debt level that might cause financial difficulties not only for the government but also for the society as a whole.

\section{References}

1. Bank of Latvia. (23 September 2014). Debt Securities (short-term and long-term). Retrieved from https://www.bank.lv/auditorijas/medijiem/264statistika/statistika-izmantotie-termini/8108-stermia-parda-vrtspapri-

2. Birka, A. (2013). Government External Debt and its Management. Retrieved from https://www.bank.lv/statistika/informacija-statistikas-lietotajiem/pazinojumi/403publikacijas/averss-un-reverss/4750-valsts-arejais-parads-un-ta-parvaldisana

3. Bua, G., Pradelli, J., Presbitero, A. (2014). Domestic public debt in Low-Income Countries: Trends and structure. Review of Development Finance, .4, 1-12. Retrieved from

https://reader.elsevier.com/reader/sd/pii/S1879933714000037?token=E3332D9A 4A29BACF3A0B3169477C94190673649C5F709BE4F38AE946C32CB18B4CB12F0B C4D158CD62CB5E468C20B7E1

4. Central Statistical Bureau database. (18 October 2019). General government debt by sub-sector and quarter at end of period (mln euro). Retrieved from https://data1.csb.gov.lv/pxweb/lv/ekfin/ekfin valdfin ikgad/VFG050.px/table/ta bleViewLayout1/

5. Central Statistical Bureau. (21 April 2015). The general government budget deficit in 2014 was $1.4 \%$ of GDP. Retrieved from https://www.csb.gov.lv/lv/statistika/statistikas-temas/ekonomika/valdibasfinanses/meklet-tema/1725-par-valsts-budzeta-deficita-un-parada

6. Dumitrescu, B. (2014). The public debt in Romania - factors of influence, scenarios for the future and a sustainability analysis considering both a finite and infinite time horizon. Procedia Economics and Finance, 8, 284. (283-292). Retrieved from https://reader.elsevier.com/reader/sd/pii/S2212567114000926?token=44A589E4 F1700AE08C66622368370129427E3CD5A72B022FAD42D2C2EFB657DD97631C9 AC6E8F81DD5F8F61002220C28

7. Fiscal Discipline Council. (2016., marts.). Latvian Government Debt. Deficit and Aging. Retrieved from https://fdp.gov.lv/files/uploaded/20161201 VParads LV.pdf

8. Fridrihsone, M. (5 January 2017). Latvia's Public Debt has Risen again and is Approaching a Historically High Level. Latvian Public Media. Retrieved from https://www.lsm.lv/raksts/zinas/ekonomika/latvijas-valsts-parads-atkalpieaudzis-un-pietuvojies-vesturiski-augstakajam-limenim.a217635/ 
9. Furman, J., Summers, L. (2019). Who`s Afraid of Budget Deficits? How Washington Should End Its Debt Obsession. Foreign Affairs, 98(2), 82.-95. Retrieved from http://web.a.ebscohost.com/ehost/pdfviewer/pdfviewer?vid=5\&sid=faab06d756dc-4a6d-92fb-015528bf7e7b\%40sessionmgr4007

10. Galinski, P. (2015). Determinants of debt limits in local governments: case of Poland. Procedia - Social and Behavioral Sciences, 213, 376-382. Retrieved from https://reader.elsevier.com/reader/sd/pii/S1877042815059091?token=FD72438B CE05B74DB7B9CF5683485295929993910655171C2FA78E8A815801B20162AEE4 2643970D044BBEAEE29EF1A6

11. Kamiguchi, A., Tamai, T. (2019). Public investments, public debt, and population aging under the golden rules of public finance. Journal of Macroeconomics, 60, 110-122. Retrieved

from https://reader.elsevier.com/reader/sd/pii/S0164070418303793?token=3B44E886 67F5FA94D166C2D77F5AF9F1F20DDE490A177A2B862A0E4B5A04DC3D52B07DA 98588FB42D9334A79D19C5784

12. Kasalis, E., Skribāne, I. (2007). Theoretical Aspects of an Analysis of a Current Account Deficit of the Balance of Payments. E. Dubra (ed.). Proceedings of the University of Latvia, Economics. (vol. 718). Riga: University of Latvia, 168-177.

13. Law on Fiscal Discipline of the Republic of Latvia. (31 January 2013). Retrieved from https://likumi.lv/ta/id/254896-fiskalas-disciplinas-likums

14. LETA. (9 March 2019). In 2018, the Government Debt Reached 10.2 Billion Euros. Retrieved from https://www.diena.lv/raksts/latvija/zinas/2018.-gada-valstsparads-sasniedzis-102-miljardus-eiro-14215875

15. Levi., M.D. (2014). The Macroeconomic Environment of Business. Core Concepts and Curious Connections. Singapore: World Scientific Publishing Co.

16. Libermanis, G. (2001). Tirgus ekonomikas pamati un Latvija ceḷā uz Eiropas Savienību. Rīga: Kamene.

17. Ludvigson, S. (1996). The macroeconomics effects of government dept in a stochastic growth model. Journal of Monetary Economics, 38 (1), 25-45.

18. Piketī, T. (2015). Kapitāls 21. gadsimtā. Rīga: Lauku bibliotēku atbalsta biedrība.

19. Regulations regarding the Classification of General Government Debt. (8 November 2005). Cabinet Regulation No. 842. Retrieved from https://likumi.lv/doc.php?id=121091

20. Reinhart, C.M., Rogoff, K.S. (2010). Growth in a Time of Debt. American Economic Review: Papers \& Proceeding. 573-578. Retrieved from https://scholar.harvard.edu/files/rogoff/files/growth in time debt aer.pdf

21. Rosen, H.S., Gayer, T. (2014). Public Finance. Glasgow: Bell and Bain Ltd.

22. Semjonova, N. (2017). Government debt: evaluation of financial security and optimal policy selection: Scientific Monograph - Riga: RTU Press.

23. Šenfelde, M. (2014). Macroeconomics. Riga: RTU Publishing House.

24. Tkačevs, O. (3 May 2011). Negative Effects of Government Debt. Retrieved from https://www.makroekonomika.lv/valdibas-parada-slikta-ietekme

25. Treasury. (3 October 2017). Interest-free Bonds. Retrieved from https://www.kase.gov.lv/valsts-parada-vadiba/bezprocentu-obligacijas

26. Treasury. [s.a.]. What are Savings Bonds? https://www.krajobligacijas.lv/static/aboutSavingNotes, Access: 29.03.2020.

27. Vilerts, K. (8 February 2018). Latvian Government Debt Development and Risks. Retrieved from https://www.makroekonomika.lv/latvijas-valdibas-parada-attistibaun-riski 